\title{
HUBUNGAN PENGETAHUAN DENGAN KEPATUHAN PERAWAT DALAM PENGGUNAAN ALAT PELINDUNG DIRI PADA RUANG SINDUR DAN AKASIA
}

\author{
${ }^{1}$ Wiwik Wahyuni, ${ }^{2}$ Luluk Sulistiyono, ${ }^{3} \mathrm{Ni}$ Wayan Rahayu Ningtyas \\ ${ }^{1,2,3}$ STIKes Borneo Cendekia Medika, Pangkalan Bun \\ Wiwikwahyuni@gmail.com
}

\begin{abstract}
ABSTRAK
Ketidakpatuhan dalam penggunaan Alat Pelindung Diri berdampak pada tertular dan menularkan penyakit pada pasien maupun sebaliknya. Salah satu ketidakpatuhan disebabkan oleh kurangnya pengetahuan perawat dalam penggunaan APD. Tujuan penelitian ini adalah menganalisis "Apakah ada hubungan antara pengetahuan dengan kepatuhan perawat dalam penggunaan Alat Pelindung Diri pada Ruang Sindur dan Akasia?" Desain penelitian yang digunakan adalah cross sectional dengan sampel sebanyak 25 responden, tehnik sampling menggunakan total sampling, data dikumpulkan dengan menggunakan alat ukur kuisioner dan observasi checklist kemudian diolah dengan editing, coding, scoring, tabulating. Selanjutnya data dianalisis univariat dengan distribusi frekuensi dan univariat dengan uji Mann Whitney. Hasil penelitian menyebutkan bahwa pengetahuan responden sebagian besar berpengetahuan baik 20 responden (80\%), kemudian kepatuhan responden dalam penggunaan APD dikategorikan sebagian besar patuh sebanyak 15 responden (60\%). Hasil uji Mann Whitney menyatakan p.value 0,000 yang berarti kurang dari 0,05 menunjukkan bahwa terdapat hubungan yang signifikan antara pengetahuan dan kepatuhan perawat dalam penggunaan APD pada ruang Sindur dan Akasia RSUD Sultan Imanuddin Pangkalan Bun Kalimantan Tengah. Disimpulkan bahwa pengetahuan responden tentang APD sebagian besar berpengetahuan baik, kepatuhan responden dalam penggunaa APD sebagian besar patuh. Terdapat hubungan antara pengetahuan dengan kepatuhan perawat dalam penggunaan Alat Pelindung Diri pada ruang Sindur dan Akasia RSUD Sultan Imanuddin Pangkalan Bun Kalimantan Tengah.
\end{abstract}

Kata Kunci: Pengetahuan, Kepatuhan, Alat Pelindung Diri 


\begin{abstract}
This study aims to determine how the relationship between knowledge and compliance of nurses in the use of personal protective equipment in the sindur and akasia room of Sultan Imanuddin Pangkalan Bun Hospital in 2021. The data analysis methods used in this study are descriptive analysis and qualitative analysis. Descriptive analysis is used to describe the variables in this study while qualitative analysis is a method of analysis that includes interviews and observations by answering questions like what, why and how. Based on the results of the study showed that the knowledge of respondents about PPE in the sindur and akasia room of Sultan Imanuddin Pangkalan Bun Hospital, at most had good knowledge as many as 20 respondents $(n=25)$, the results of respondents' compliance with the use of PPE in sindur and acacia rooms at Sultan Imanuddin Pangkalan Bun Hospital at most 15 respondents $(n=25)$, and there is a relationship between knowledge and the use of PPE in the sindur and akasia room at the Sultan Imanuddin Pangkalan Bun Regional Hospital with the results of the Spearman correlation with a p-value of $0.000<0.05$.
\end{abstract}

Keywords: Knowledge, Nurse Compliance, Personal Protective Equipment

\section{PENDAHULUAN}

Rumah Sakit merupakan pusat dimana pelayanan kesehatan masyarakat di selenggarakan (Association of Hospital Care; 1947). Rumah sakit tidak hanya menjadi tempat pengobatan, tetapi bisa juga menjadi sumber infeksi bagi orang lain (Septiari, 2012). Seluruh tenaga kesehatan dirumah sakit harus dijaga keamanannya dari penularan semua jenis penyakit, apalagi di saat pandemik Covid-19 pada tahun 2020. Upaya menjaga keamanan dan kenyamanan tenaga kesehatan oleh tertularnya penyakit pihak manajemen mewajibkan kepada seluruh tenaga kesehatan ketika melakukan pelayanan kepada pasien untuk selalu menggunakan alat pelindung diri (APD). Hal ini sesuai dengan peraturan pemerintah/ KEMENKES Nomor 52 tahun 2018. Seperti halnya panduan pemakaian APD yang ditetapkan oleh Direktur Rumah Sakit Imanuddin pada tanggal 21 Maret 2020 bahwa tenaga kesehatan yang bertugas dalam melakukan perawatan yang menimbulkan aerosol seperti pemberian Inhalasi atau Nebulizer diwajibkan menggunakan APD diantaranya apron atau gown, penutup kepala, sepatu tertutup, masker N95, google atau kacamata, dan sarung tangan.

Namun sering didapatkan informasi bahwa tidak jarang para tenaga kesehatan sering terinfeksi oleh TBC Salah satu penyebabnya adalah ketidakpatuhan dalam penggunaan APD sehingga menciptakan ruang dimana mikroorganisme pathogen dapat masuk pada diri para medis. Beberapa faktor para tenaga kesehatan tidak patuh dalam penggunaan APD meliputi kurangnya pengetahuan, kurangnya waktu, kelupaan, kurangnya keterampilan, ketidaknyamanan, iritasi kulit, dan 
kurangnya pelatihan (Efstathiou et al, 2011). Salah satunya adalah kurangnya pengetahuan yang menyebabkan ketidaktahuan tenaga kesehatan akan manfaat APD pada dirinya.

Infeksi yang terjadi di rumah sakit disebut Healtcare - associated Infections (HAIs). Menurut survei di Inggris, prevalensi keseluruhan HAIs sekitar $6,4 \%$, dimana $22,8 \%$ diantaranya infeksi saluran pernafasan dan $17,2 \%$ infeksi saluran kemih (ISK), berkisar $15,7 \%$ infeksi luka operasi (ILO), demikian juga dengan clinical sepsis sebesar 10,5\%, infeksi saluran pencernaan sebesar $8,8 \%$ dan Bloodstream Infections (BSI) atau infeksi aliran darah primer (IADP) sebesar 7,3\% (Health Protection Agency, 2012).

Angka kejadian HAIs di Indonesia yang mengambil dari survei10 Rumah Sakit Umum Pendidikan, didapatkan angka kejadian HAIs sebanyak 6-16\% dengan rerata 9,8\% (Cahyo, 2014). Penelitian yang pernah dilakukan di 11 Rumah Sakit di DKI Jakarta pada tahun 2004 menunjukkan bahwa 9,8\% pasien rawat inap mendapat infeksi baru selama di rawat. Angka kejadian HAIs di Rumah Sakit Sultan Imanuddin Pangkalan Bun triwulan I tahun 2019 diantaranya yang terdiri dari 8 ruang perawatan yang dilakukan surveilan, dapat dilihat pada bulan Januari angka phlebitis tertinggi berada di ruang Meranti (29 orang), bulan Februari di ruang Sindur (21 orang), dan Maret (21 orang). Hal ini disebabkan karena dalam melakukan tindakan keperawatan, perawat lalai dalam pemakaian APD khususnya saat pemasangan infus, ada beberapa perawat yang tidak menggunakan Handscoon.
Hasil observasi di Ruang Sindur dan Akasia Rumah Sakit Sultan Imanuddin Pangkalan Bun Kalimantan Tengah yang terdapat 30 perawat. Observasi terhadap 5 perawat, dimana 2 orang perawat menggunakan sepasang sarung tangan dalam melakukan beberapa tindakan, 1 orang perawat tidak menggunakan sarung tangan dengan semestinya saat memperbaiki infus pasien yang macet, serta 2 orang perawat yang masih menggunakan masker saat menulis rekam medis, dan hasil wawancara terhadap 5 orang perawat tersebut mengenai pengetahuan tentang penggunaan APD, didapatkan hasil bahwa 3 orang perawat tidak bisa menyebutkan pentingnya penggunaan APD dalam pencegahan dan mengurangi risiko penularan.

Perawat merupakan petugas kesehatan yang paling sering berinteraksi dengan pasien, sehingga resiko tertular dan menularkan penyakit sangatlah tinggi jika tidak mematuhi penggunaan APD. Faktor yang mempengaruhi pada kepatuhan penggunaan APD yaitu faktor Intrinsik dan faktor Ekstrinsik. Faktor Intrinsik terdiri dari usia, jenis kelamin, pendidikan, pengetahuan, masa kerja, dan sikap. Sedangkan faktor Ekstinsik terdiri dari peraturan tentang penggunaan APD, kelengkapan alat, kenyamanan pemakaian alat, dan pengawasan terhadap penggunaan APD. Salah satu faktor intrinsik yang mempengaruhi kepatuhan penggunaan APD adalah pengetahuan. Notoatmodjo (2010) menyatakan bahwa pengetahuan yang baik akan mewujudkan perilaku kepatuhan dalam penggunaan alat pelindung diri selama bekerja, 
khususnya dalam memberikan asuha keperawatan.

Kepatuhan merupakan suatu perubahan perilaku, dari yang tidak menaati peraturan ke perilaku yang menaati peraturan (Notoadmodjo, 2007). Kepatuhan perawat dalam penggunaan alat pelindung diri adalah perilaku perawat yang patuh akan pemakaian APD dalam melakukan tindakan keperawatan. Masih banyaknya kejadian terinfeksinya oleh pathogen karena tidak menggunakan APD salah satunya disebabkan oleh ketidaktahuan akan pentingnya APD bagi tenaga perawat. Pengetahuan perawat tentang APD adalah pemahaman perawat mengenai hal yang berkaitan dengan APD sehingga mengaplikasikan dalam bentuk sikap saat melakukan tindakan keperawatan. Pengetahuan tentang cara menggunakan APD yang baik akan mewujudkan perilaku kepatuhan penggunaan APD selama bekerja (Notoatmodjo, 2010).

Berdasarkan Latar Belakang diatas penulis merumuskan permasalahan, yaitu: "Apakah ada Hubungan Pengetahuan dengan Kepatuhan Perawat dalam Penggunaan Alat Pelindung Diri pada Ruang Sindur dan Akasia RSUD Sultan Imanuddin Pangkalan Bun Kalimantan Tengah".

Penelitian ini bertujuan untuk mengidentifikasi pengetahun perawat tentang alat pelindung diri, mengidentifikasi kepatuhan perawat dalam penggunaan alat pelindung diri, dan menganalisis hubungan pengetahuan dengan kepatuhan perawat dalam penggunaan alat pelindung diri di ruang sindur dan akasia.

Manfaat dari penelitian ini secara teoritis adalah dapat menjadi tambahan pengetahuan terkait dengan perbendaharaan keilmuan tentang pengetahuan dan kepatuhan perawat dalam penggunaan alat pelindung diri saat memberikan pelayanan keperawatan. Dan secara praktis bermanfaat bagi Rumah Sakit, bagi perawat, bagi peneliti selanjutnya, dan bagi institusi pendidikan kesehatan.

Perawat adalah seseorang yang mempunyai kemampuan, tanggung jawab dan kewajiban melaksanakan pelayanan/asuhan keperawatan pada berbagai jenjang pelayanan keperawatan (Kusnanto, 2003).

Perawat memiliki beberapa peran, yaitu:

1) Pemberi Asuhan Keperawatan

Perawat memberikan layanan berupa asuhan keperawatan secara langsung kepada pasien sesuai dengan kewenangannya. Asuhan keperawatan diberikan kepada pasien menggunakan metodologi proses keperawatan yang berpedoman pada standar keperawatan dilandasi oleh etik dan etika keperawatan serta berada dalam lingkup wewenang dan tanggung jawab keperawatan.

2) Pembuat Keputusan Klinis

Dalam memberikan asuhan keperawatan, perawat dituntut untuk dapat membuat keputusan sehingga tercapai perawatan yang efektif.

3) Pengelola (manajer)

Perawat mempunyai peran dan tanggung jawab dalam mengelola layanan keperawatan di semua tatanan layanan kesehatan (rumah sakit, puskesmas, dan sebagainya) sesuai konsep manajemen keperawatan.

4) Pelindung dan Advokat Pasien 
Perawat membantu mempertahankan lingkungan yang aman bagi pasien dari kemungkinan efek yang tidak diinginkan dari suatu tindakan diagnostik atau pengobatan. Perawat melindungi hak pasien sebagai manusia dan secara hukum, serta membantu pasien dalam menyatakan hak-hak bila dibutuhkan.

5) Manajer Kasus

Perawat mengkoordinasikan dan mendelegasikan tanggung jawab asuh hak keperawatan dan mengawasi tenaga kesehatan lainnya.

6) Rehabilitator

Rentang rehabilitasi mulai dari mengajarkan pasien untuk mengubah pola hidup pasien yang mengalami penyakit kronik.

7) Pemberi kenyamanan

Perawat memberi kenyamanan dengan membantu pasien untuk mencapai tujuan yang terpenting bukan memenuhi ketergantungan emosi dan fisiknya.

8) Komunikator

Dalam melakukan perannya, seorang perawat harus melakukan komunikasi dengan baik.

9) Penyuluh atau pendidik

Perawat memberikan pengajaran kepada pasien tentang kesehatan sesuai dengan kemampuan dan kebutuhan klien serta melibatkan sumber-sumber lainnya.

10) Role Model

Perawat harus dapat menjadi panutan dan dapat memberikan contoh bagi pasiennya. Baik dalam berperilaku, sikap maupun penampilan secara fisik.

11) Pengendali Infeksi
Perawat menyediakan pelayanan konsultasi tentang aspek pencegahan dan pengendalian infeksi dengan cara menggunakan metode berdasarkan bukti penelitian.

12) Peneliti

Sebagai peneliti dibidang keperawatan perawat diharapkan mampu mengidentifikasi masalah penelitian, menerapkan prinsip dan metode penelitian serta memanfaatkan hasil penelitian untuk meningkatkan mutu asuhan atau pelayanan dan pendidikan keperawatan.

13) Kolaborator

Perawat dalam proses

keperawatan dapat melakukan kolaborasi dengan tenaga kesehatan lainnya untuk mencapai pemenuhan kebutuhan pasien.

Fungsi keperawatan terdiri dari fungsi keperawatan mandiri, ketergantungan dan kolaboratif. Fungsi keperawatan mandiri adalah aktivitas keperawatan yang dilaksanakan atas inisiatif perawat itu snediri dengan dasar pengetahuan dan keterampilannya. Fungsi keperawatan ketergantungan adalah aktifitas keperawatan yang dilaksanakan atas instruksi dokter atau dibawah pengawasan dokter dalam melaksanakan tindakan rutin yang spesifik. Fungsi keperawatan kolaboratif adalah aktifitas yang dilaksanakan atas kerja sama dengan pihak lain atau tim kesehatan lain. Untuk melaksanakan praktik keperawatan kolaboratif secara efektif, perawat harus mempunyai kemampuan klinis, mempunyai pengetahuan dan keterampilan yang memadai dan rasa 
pertanggungjawaban yang tinggi dalam setiap tindakan.

Secara umum perawat mempunyai tanggung jawab dalam memberikan asuhan/pelayanan keperawatan, meningkatkan ilmu pengetahuan dan meningatkan diri sebagai profesi. Tanggung jawab dalam memberikan asuhan keperawatan kepada pasien dalam upaya pemenuhan kebutuhan dasarnya dengan menggunakan pendekatan proses keperawatan yaitu, membantu pasien memperoleh kembali kesehatannya, memelihara kesehatan pasien, membantu pasien yang tidak bisa sembuh untuk menerima kondisinya dan membantu pasien yang menghadapi ajal untuk diperlukan secara manusiawi sesuai martabatnya sampai meninggal dengan tenang.

Alat pelindung diri (APD) adalah suatu alat yang dirancang memiliki kemampuan melindungi seseorang selama bekerja dari bahaya di tempat kerja. Kekurangan selama dalam penggunaan APD adalah tidak sempurnanya kemampuan perlindungan yang dimiliki APD tersebut. Alat pelindung diri terdiri dari pelindung mata (perisai muka, kacamata), kap, sarung tangan, masker/respirator, gaun, apron, dan barang lainnya.

Pengetahuan berasal dari kata "tahu", dalam Kamus Besar Bahasa Indonesia (2008) kata tahu memiliki arti mengerti sesudah melihat. Menurut Mubarak (2011) menjelaskan bahwa pengetahuan merupakan segala sesuatu yang diketahui berdasarkan pengalaman, dan pengetahuan akan bertambah sesuai dengan proses pengalaman yang dialaminya. Pengetahuan yang dicakup di dalam domain kognitif menurut Notoatmodjo (2003) mempunyai 6 tingkat, yakni tahu (know), memahami (comprehension), aplikasi (Application), analisis (analysis), sintesis (synthesis), dan evaluasi (Evaluation).

Menurut Budiman dan Riyanto (2013), faktor yang mempengaruhi pengetahuan antara lain pendidikan, informasi atau media massa, sosial budaya dan ekonomi, lingkungan, pengalaman, dan usia. Pengukuran pengetahuan dapat dilakukan dengan wawancara atau angket yang menanyakan tentang isi materi yang ingin diukur dari subjek penelitian atau responden (Notoadmodjo, 2010). Untuk mengukur pengetahuan secara umum dibagi menjadi 2 jenis pertanyaan, yaitu:

a) Pertanyaan subjektif

Pertanyaan subjektif merupakan jenis pertanyaan essay.

b) Pertanyaan objektif

Pertanyaan objektif merupakan jenis pertanyaan dengan pilihan ganda (multiple choise), betul salah dan pertanyaan menjodohkan dapat dinilai secara pasti oleh penilai. Arikunto (2010) menjelaskan pengukuran tingkat pengetahuan dapat dikategorikan menjadi tiga yaitu:

1) Pengetahuan baik apabila responden dapat menjawab 76 $100 \%$ dengan benar dari total jawaban pertanyaan.

2) Pengetahuan cukup apabila responden dapat menjawab 56 $75 \%$ dengan benar dari total jawaban pertanyaan.

3) Pengetahuan kurang apabila responden dapat menjawab < $56 \%$ dari total jawaban pertanyaan. 
Kepatuhan berasal dari kata patuh yang berarti taat, suka menurut perintah. Notoatmodjo (2003) menjelaskan kepatuhan merupakan perilaku pemeliharaan kesehatan seseorang untuk menjaga kesehatan agar tidak sakit dan melakukan upaya penyembuhan apabila sakit. Kepatuhan yang baik mencerminkan besarnya rasa tanggung jawab seseorang terhadap tugas-tugas yang diberikan kepadanya. Perilaku kesehatan sangat berpengaruh kepada kepatuhan seseorang, yang pada dasarnya perilaku kesehatan merupakan respon seseorang terhadap stimulus yang berkaitan dengan sakit dan penyakit, sistem pelayanan kesehatan serta lingkungan.

Faktor yang mempengaruhi kepatuhan penggunaan alat pelindung diri antara lain faktor internal yang terdiri dari pengetahuan dan sikap, dan faktor eksternal yang terdiri dari penyuluhan, pengawasan, dan kelengkapan APD.

Pengukuran tingkat kepatuhan perawat dalam menggunakan alat pelindung diri dapat diukur pada saat melakukan tindakan keperawatan, dengan kriteria objektif antara lain: Di nyatakan perawat patuh dalam penggunan APD jika perawat telah menggunakan seluruh APD sesuai dengan ketentuan yang telah ditetapkan. Dinyatakan tidak patuh jika perawat tidak menggunakan salah satu atau lebih APD dan prosedur yang harus dilakukan.

Bekerja di Rumah sakit mempunyai risiko tertular penyakit yang diakibatkan oleh virus, bakteri dan mikroorganisme pathogen lainnya. Dalam bekerja seorang petugas kesehatan harus memperhatikan prosedur kerja dan menggunakan
APD sebagai salah satu cara untuk mencegah terjadinya risiko terkena penyakit akibat kerja atau kecelakaan akibat kerja. Oleh karena itu APD digunakan untuk mengendalikan bahaya serta mengurangi risiko. Apabila petugas tidak menggunakan pengaman, akan semakin besar kemungkinan terinfeksi bahan berbahaya, khususnya berbagai jenis virus, bakteri maupun mikroorganisme pathogen lain. Pentingnya pengetahuan perawat dalam penggunaan APD sehingga akan di aplikasikan dalam bentuk sikap saat melakukan tindakan keperawatan. Jika perawat sudah memahami secara mendalam tentang manfaat APD bahwa alat pelindung diri akan menjamin keamanan dan kenyamanan kesehatan mereka dan juga bermanfaat bagi keluarganya dan hal ini akan tersimpan dalam memori maka akan di implementasikan dan diaktualisasikan diri menjadi perilaku yang kontinyu. Hal ini sesuai pendapat Kartono 1990 dalam Khodijah (2016) yang menyatakan bahwa segala sesuatu yang telah diketahui, difahami dan tersimpan dalam memori maka seseorang akan berperilaku secara terus-menerus yang sama.

\section{METODE PENELITIAN}

Penelitian dilaksanakan di Ruang Sindur dan Akasia RSUD Sultan Imanuddin Pangkalan Bun Kabupaten Kotawaringin Barat Kalimantan Tengah dimulai dari melakukan identifikasi masalah sampai dengan penyusunan laporan akhir dimulai sejak bulan Mei 2020 sampai dengan bulan Juni 2020. Adapun pengumpulan data dan seterusnya sampai dengan penyusunan laporan 
akhir dilaksanakan pada bulan Agustus 2020 - Maret 2021. Desain penelitian menggunakan metode penelitian deskriptif kuantitatif dengan pendekatan cross-sectional. Populasi dalam penelitian ini adalah semua perawat yang bekerja di ruang sindur dan akasia RSUD Sultan Imanuddin Pangkalan Bun Kalimantan Tengah sebanyak 25 perawat. Sampel yang diambil yaitu seluruh perawat (25 responden) yang bekerja diruang Sindur dan Akasia RSUD Sultan Imanuddin Pangkalan Bun Kalimantan Tengah dengan menggunakan teknik sampel jenuh atau total sampling dimana semua perawat yang bekerja di ruang Sindur dan Akasia merupakan sampel dari penelitian ini. Instrumen penelitian terdiri dari kuesioner data demografi yang berisi nama, jenis kelamin, umur, pendidikan terakhir, dan lama bekerja, kuesioner untuk mengukur tingkat pengetahuan, dan lembar observasi. Analisis data terdiri dari dua yaitu analisis univariate dan analisis bivariat dengan menggunakan uji Mann whitney

\section{HASIL DAN PEMBAHASAN}

\section{Deskripsi Lokasi Penelitian}

RSUD Imanuddin adalah rumah sakit milik pemerintah daerah Kotawaringin Barat Kelas B yang terletak di Jln.Sutan Syahrir No.17 Pangkalan Bun Kotawaringin Barat Kalimantan Tengah. Rumah sakit ini didirikan sejak jaman Belanda dan sebelumnya berlokasi di Kelurahan Raja. Luas lahan Rumah sakit ini 53.426,67 $\mathrm{m}$ dengan luas bangunan $13.333,70 \mathrm{~m}$ dan kapasitas tempat tidur 233. Diantaranya terdiri dari ruang VIP 16 tempat tidur, kelas I 36 tempat tidur, kelas II 46 tempat tidur, kelas III 79 tempat tidur, intensif 11 tempat tidur serta 45 tempat tidur lainlain. Visi, Misi dan Motto RSUD Sultan Imanuddin Pangkalan Bun adalah:

1) Visi RSUD Sultan Imanuddin Pangkalan Bun

Visi RSUD Sultan Imanuddin Pangkalan Bun adalah "Rumah Sakit Mandiri Dengan Pelayanan Prima".

2) Misi RSUD Sultan Imanuddin Pangkalan Bun

Adapun misi RSUD Sultan Imanuddin Pangkalan Bun adalah:

(1) Mewujudkan pengelolaan Rumah Sakit yang profesional dengan prinsip sosial ekonomi secara efektif dan efisien serta mampu berdaya saing.

(2) Meningkatkan kualitas sumber daya Rumah Sakit yang profesional, produktif dan berkomitmen sesuai dengan sperkembangan ilmu kedokteran / kesehatan.

(3) Meningkatkan mutu pelayanan kesehatan kepada semua lapisan masyarakat secara cepat, tepat, nyaman dan terjangkau dengan dilandasi etika profesi.

3) Motto RSUD Sultan Imanuddin Pangkalan Bun

Motto RSUD Sultan Imanuddin Pangkalan Bun adalah "Pelayanan Yang Memuaskan Adalah Tekad Kami".

RSUD Sultan Imanuddin Pangkalan Bun mempunyai 8 ruang perawatan, salah satunya adalah ruang penyakit dalam. Ruang penyakit dalam dibagi menjadi 2 ruangan yaitu ruang Sindur dan Akasia. Jumlah perawat keseluruhan adalah 30 perawat dimana Sindur terdiri 15 perawat dan 
Akasia terdiri 15 perawat, dimana kedua ruang tersebut masing-masing terdiri dari 1 Kepala ruangan, 2 orang ketua tim dan 13 perawat pelaksana.

\section{Data Umum}

Tabel 1. Karakteristik Responden Berdasarkan Usia di Ruang Sindur dan Akasia RSSI Maret $2021(\mathrm{n}=25)$

\begin{tabular}{ccc}
\hline Kategori & Frekuensi & Persentase \\
\hline $\mathbf{1 7}-\mathbf{2 5}$ tahun & 2 & $8 \%$ \\
$\mathbf{2 6}-\mathbf{3 5}$ tahun & 14 & $56 \%$ \\
$\mathbf{3 6}-\mathbf{4 5}$ tahun & 8 & $32 \%$ \\
$\mathbf{4 6}-\mathbf{5 5}$ tahun & 1 & $4 \%$ \\
\hline Total & $\mathbf{2 5}$ & $\mathbf{1 0 0 \%}$ \\
\hline
\end{tabular}

Tabel 2. Karakteristik Responden Berdasarkan Jenis Kelamin di Ruang Sindur dan Akasia RSSI, Maret 2021 (n = 25)

\begin{tabular}{ccc}
\hline $\begin{array}{c}\text { Jenis } \\
\text { Kelamin }\end{array}$ & Frekuensi & Presentase \\
\hline Perempuan & 20 & $80 \%$ \\
Laki-laki & 5 & $20 \%$ \\
\hline Total & 25 & $100 \%$ \\
\hline
\end{tabular}

Tabel 3. Karakteristik Responden Berdasarkan Pendidikan di Ruang Sindur dan Akasia RSSI Pangkalan Bun, Maret $2021(\mathrm{n}=25)$

\begin{tabular}{ccc}
\hline Pendidikan & Frekuensi & Presentase \\
\hline SPK & 3 & $12 \%$ \\
DIII & 15 & $60 \%$ \\
S1 & 6 & $24 \%$ \\
S2 & 1 & $4 \%$ \\
\hline Total & $\mathbf{2 5}$ & $\mathbf{1 0 0 \%}$
\end{tabular}

Tabel 4. Karakteristik Responden Berdasarkan Masa Kerja di Ruang Sindur dan Akasia, Maret $2021(\mathrm{n}=25)$

\begin{tabular}{ccc}
\hline $\begin{array}{c}\text { Masa } \\
\text { Kerja }\end{array}$ & Frekuensi & Presentase \\
\hline$<\mathbf{5}$ tahun & 9 & $36 \%$ \\
$>\mathbf{5}$ tahun & 16 & $64 \%$ \\
\hline Total & $\mathbf{2 5}$ & $\mathbf{1 0 0 \%}$ \\
\hline
\end{tabular}

Tabel 5. Karakteristik Responden Berdasarkan Pelatihan di Ruang Sindur dan Akasia, Maret $2021(n=25)$

Pernah dan Frekuensi Presentase

\begin{tabular}{|c|c|c|}
\hline \multicolumn{3}{|l|}{ Tidak Pelatihan } \\
\hline Pernah Pelatihan & 5 & $20 \%$ \\
\hline Tidak Pelatihan & 20 & $80 \%$ \\
\hline Total & 25 & $100 \%$ \\
\hline $\begin{array}{ll}\text { Tabel } \quad 6 . & \mathrm{K} \\
\text { Berdasarkan } & \text { Inf } \\
\text { dan Akasia } & \text { RSS }\end{array}$ & $\begin{array}{l}\text { Karakteristik } \\
\text { nformasi di } \\
\text { SI, Maret } 20\end{array}$ & $\begin{array}{l}\text { k Responden } \\
\text { Ruang Sindur } \\
021(\mathrm{n}=25)\end{array}$ \\
\hline Informasi & Frekuensi & Presentase \\
\hline Televisi & - & $12 \%$ \\
\hline Internet & 0 & $24 \%$ \\
\hline Famflet RS & 16 & $64 \%$ \\
\hline Total & 25 & $100 \%$ \\
\hline Data Khusus & & \\
\hline $\begin{array}{l}\text { Tabel } 7 . \\
\text { Mengenai Alat } \\
\text { Ruang Sindur d } \\
=25)\end{array}$ & $\begin{array}{l}\text { Frekuensi } \\
\text { Pelindung } \\
\text { dan Akasia, }\end{array}$ & $\begin{array}{l}\text { Pengetahuan } \\
\text { Diri (APD) di } \\
\text { Maret } 2021\end{array}$ \\
\hline Pengetahuan & & \\
\hline $\begin{array}{c}\text { Mengenai } \\
\text { APD }\end{array}$ & Frekuensi & Persentase \\
\hline & 20 & $80 \%$ \\
\hline Cukup & 5 & $20 \%$ \\
\hline Kurang & 0 & $0 \%$ \\
\hline Total & 25 & $100 \%$ \\
\hline
\end{tabular}

Tabel 8. Frekuensi Kepatuhan Penggunaan Alat Pelindung Diri (APD) di Ruang Sindur dan Akasia, Maret 2021 $(\mathrm{n}=25)$

\begin{tabular}{ccc}
\hline $\begin{array}{c}\text { Kepatuhan } \\
\text { Penggunaan } \\
\text { APD }\end{array}$ & Frekuensi & Persentase \\
\hline Patuh & 15 & $60 \%$ \\
Tidak Patuh & 10 & $40 \%$ \\
\hline Total & $\mathbf{2 5}$ & $\mathbf{1 0 0 \%}$ \\
\hline
\end{tabular}

Tabel 9. Analisa Hubungan dan Tabulasi Silang Pengetahuan dengan Kepatuhan Penggunaan Alat Pelindung Diri di Ruang Sindur dan Akasia, Maret 2021 (n $=25$ )

\begin{tabular}{|c|c|c|c|}
\hline \multirow{2}{*}{$\begin{array}{l}\text { Pengetahuan } \\
\text { Mengenai } \\
\text { APD }\end{array}$} & \multicolumn{2}{|c|}{$\begin{array}{c}\text { Kepatuhan } \\
\text { Penggunaan } \\
\text { APD }\end{array}$} & \multirow{2}{*}{$\begin{array}{c}\text { Total } \\
(\%)\end{array}$} \\
\hline & $\begin{array}{c}\text { Patuh } \\
(\%)\end{array}$ & $\begin{array}{c}\text { Tidak } \\
\text { Patuh } \\
(\%)\end{array}$ & \\
\hline Baik & $\begin{array}{c}13 \\
(52 \%)\end{array}$ & $\begin{array}{c}7 \\
(28 \%)\end{array}$ & $\begin{array}{c}20 \\
(80 \%)\end{array}$ \\
\hline Cukup & $\begin{array}{c}2 \\
(8 \%)\end{array}$ & $\begin{array}{c}3 \\
(12 \%)\end{array}$ & $\begin{array}{c}5 \\
(20 \%)\end{array}$ \\
\hline Kurang & $0(0 \%)$ & $0(0 \%)$ & $0(0 \%)$ \\
\hline
\end{tabular}




\begin{tabular}{lccc}
\hline \multirow{2}{*}{ Total } & 15 & 10 & 25 \\
& $(60 \%)$ & $(40 \%)$ & $(100 \%)$ \\
\hline $\boldsymbol{p}$-value & \multicolumn{3}{c}{0,000} \\
\hline
\end{tabular}

\section{Pembahasan}

Dari hasil penelitian berdasarkan tabel 7 didapatkan data dari 25 responden sebanyak 20 responden $(80 \%)$ memiliki pengetahuan mengenai alat pelindung diri baik. Pengetahuan baik responden tentang APD dapat diketahui karena responden memahami tentang pengertian APD, jenis APD, pemeliharaan APD, manfaat APD dan juga memahami cara pemakaian.

Pengetahuan baik responden tentang APD karena $100 \%$ responden mengetahui tentang pengertian Alat Pelindung Diri, sebagaimana hasil kuesioner responden menyatakan, yang dimaksud dengan Alat Pelindung Diri adalah suatu alat yang digunakan untuk melindungi bagian tubuh dari percikan ataupun cairan dari pasien. Hal ini sesuai dengan peraturan menteri tenagakerja dan transmigrasi Republik Indonesia nomor PER.08/MEN/VII 2010 tentang alat pelindung diri, APD adalah suatu alat yang mempunyai kemampuan untuk melindungi seseorang yang fungsinya mengisolasi sebagian atau seluruh tubuh dari potensi bahaya ditempat kerja.

Responden juga memahami tentang jenis APD 100\%. Responden memahahi jenis APD yang meliputi masker, apron, sarung tangan, topi, goggles dan pelindung kaki. Hal ini sesuai dengan pendapat Buntarto (2015) menjelaskan macam-macam APD terdiri dari pakaian pelindung (apron), pelindung kepala (topi), pelindung tangan, pelindung kaki, pelindung mata (goggles), dan masker.

Responden dalam penelitian ini hampir seluruhnya memahami cara pemeliharaan APD sebanyak (96\%). Cara merawat APD antara lain dengan mencuci bersih, disemprot alkohol atau cairan desinfektan supaya bakteri ataupun pathogen lainnya bisa mati, dijemur dibawah sinar matahari, selanjutnya disimpan pada tempat yg aman dan bersih. Hal ini sesuai dengan pendapat Tarwaka (2017) menyatakan prinsip perawatan APD secara umum dilakukan dengan cara mencuci dengan air sabun, kemudian dibilas dengan air secukupnya, menjemur dipanas matahari untuk menghilangkan bau dan mencegah tumbuhnya jamur dan bakteri, mengganti filter atau catridge untuk respirator setelah dipakai beberapa kali.

Responden memahami manfaat APD sebanyak (92\%). Manfaat APD adalah untuk melindungi bagian tubuh dari potensi bahaya atau kecelakaan kerja serta mengurangi risiko tertularnya penyakit. Hal ini sejalan dengan pendapat Menaker (2010) menyatakan APD adalah suatu alat yang fungsinya mengisolasi sebagian atau seluruh tubuh dari potensi bahaya di tempat kerja.

Responden dalam penelitian ini memahami cara penggunaan APD sebanyak (80\%). Sebelum memakai APD cuci tangan terlebih dahulu kemudian memakai gaun dilanjutkan dengan sepatu kerja khusus, selanjutnya memakai topi bedah sekali pakai, kemudian memakai masker, dilanjutkan memakai goggles dan terakhir sarung tangan. Hal ini sesuai dengan peraturan Direktur RSUD Sultan Imanuddin Pangkalan 
Bun Nomor 1 tahun 2020 tentang kebijakan pelayanan.

Pemahaman responden mulai dari pengertian, jenis, cara pemeliharaan, manfaat, serta cara penggunaan APD mendekati sempurna karena ditunjang oleh beberapa faktor antara lain pendidikan, dimana pada penelitian ini didapatkan perawat yang berpendidikan tinggi sebanyak $88 \%$. Dimana pada pendidikan tinggi khususnya bidang keperawatan terdapat mata kuliah tentang APD. Faktor lainnya adalah masa kerja yang rata-rata telah mencapai lebih dari 5 tahun sebanyak $64 \%$, semakin lama masa kerja maka informasi dan pengalaman yang didapat akan semakin banyak tidak terkecuali tentang APD. Selain itu adanya informasi juga mempengaruhi pemahaman responden, responden mendapatkan informasi dari famlet yang dibuat rumah sakit sebanyak $64 \%$, semakin banyak dan sering informasi didapat akan meningkatkan pengetahuan dan menambah wawasan responden.

Kepatuhan menggunakan masker, apron, sarung tangan, pelindung mata (goggles), penutup kepala seluruhnya $100 \%$ karena responden memahami masker memiliki fungsi untuk melindungi saluran pernafasan dari percikan bersin dan batuk orang lain. Hal ini sesuai dengan WHO (2020) menjelaskan kegunaan masker medis adalah salah satu langkah pencegahan yang dapat membatasi penyebaran penyakit-penyakit saluran pernafasan tertentu yang diakibatkan oleh virus.

Responden memahami apron berfungsi untuk melindungi lengan dan area tubuh perawat dari paparan virus selama melakukan prosedur penanganan dan perawatan pasien.
Hal ini sesuai dengan pendapat Permenakertrans Nomor 8 Tahun 2010 menjelaskan bahwa pakaian pelindung (apron) berfungsi untuk melindungi sebagian atau seluruh badan dari bahaya temperatur panas, percikan bahan-bahan kimia, cairan dan logam panas atau dingin yang ekstrem, pejanan api dan benda-benda pnas, percikan bahan kimia, cairan dan logam panas, mikro-organisme pathogen dari manusia, binatang, tumbuhan dan lingkungan seperti virus, bakteri dan jamur.

Responden memahami fungsi sarung tangan adalah untuk melindungi tangan dari potensi bahaya saat melakukan tindakan keperawatan. Hal ini sesuai dengan ketentuan Depkes RI (2007) penggunaan sarung tangan bertujuan untuk membantu petugas kesehatan untuk melindungi tangan dari kontak dengan darah, semua jenis cairan tubuh, sekret, ekskreta, kulit yang tidak utuh, selaput lendir dan benda yang terkontaminasi.

Responden memahami penggunaan pelindung mata (goggles) untuk melindungi mata dari resiko terpapar oleh objek atau benda asing yang dapat mengakibatkan cedera pada mata dan gangguan penglihatan lainnya. Hal ini sesuai dengan ketentuan Kemenkes RI (2017) yang menjelaskan tujuan pemakaian goggles dan perisai wajah adalah untuk melindungi mata dan wajah dari percikan darah, cairan tubuh, sekresi dan ekskresi.

Responden memahami fungsi kegunaan penutup kepala adalah untuk melindungi kepala dari resiko terpaparnya objek atau benda asing yang dapat mengakibatkan cedera pada kepala. Hal ini sesuai dengan ketentuan Permenkes RI (2017) yang 
menjelaskan penutup kepala digunakan untukmenutup rambut dan kulit kepala yang harus cukup besar sehingga serpihan kulit dan rambut tidak masuk kedalam luka selama pembedahan dan melindungi pemakainya dari percikan darah dan cairan tubuh.

Namun demikian responden hanya $60 \%$ yang penggunaan alas kaki khusus, karena responden mengatakan penggunaan alat kaki khusus cenderung lama, berat dan tidak praktis, sehingga yang bersangkutan hanya menggunakan alas kaki biasa atau sandal. Sebagaimana sifat manusia yang ingin melakukan sesuatu secara cepat dan sederhana sesuai dengan tipe kepribadian menurut Spranger dalam Fudyartanta (2012) yang salah satunya adalah tipe ekonomis yang menggambarkan sebagai sesorang yang minatnya terpusat pada nilai guna sesuatu, apa yang berguna baginya.

Berdasarkan hasil uji Mann Whitney terdapat data $p$-value $0,000<0,05$ yang artinya hipotesis $\mathrm{H}_{1}$ di nyatakan diterima. Terdapat hubungan yang signifikan antara Pengetahuan dan Kepatuhan Dalam Penggunaan Alat Pelindung Diri Pada Ruang Sindur dan Akasia RSUD Sultan Imanuddin Pangkalan Bun Kalimantan Tengah. Hal ini sejalan dengan penelitian yang dilakukan oleh penelitian Azzahri (2019) tentang hubungan pengetahuan tentang penggunaan alat pelindung diri (APD) dengan kepatuhan penggunaan APD pada perawat di Puskesmas Kuok bahwa terdapat hubungan pengetahuan dengan penggunaan alat pelindung diri dengan $p$-value 0,003 .

Kepatuhan penggunaan alat pelindung diri dengan rata-rata kepatuhan mencapai 93\%. Karena responden memahami manfaat alat pelindung diri dan dampak yang di timbulkan jika tidak menggunakan APD, sebagaimana diketahui bahwa manfaat APD oleh responden adalah untuk melindungi diri dari bahaya atau kecelakaan kerja. Hal ini sesuai dengan Peraturan Menteri Tenaga Kerja dan Transmigrasi Nomor PER.08/MEN/VII/2010 yang menjelaskan APD adalah alat yang memiliki kemampuan untuk melindungi seseorang yang fungsinya mengisolasi sebagian atau seluruh tubuh dari potensi bahaya di tempat kerja.

Demikian halnya dengan pemahaman terhadap dampak yang ditimbulkan jika tidak menggunakan alat pelindung diri. Responden memahami bahwa jika tidak memakai APD akan menimbulkan kecelakaan dan gangguan kesehatan. Hal ini sesuai dengan pendapat Pratiwi (2012) menjelaskan tindakan tidak aman (unsafe action) adalah tindakan yang dapat membahayakan pekerja maupun orang lain dan menyebabkan terjadinya kecelakaan yang disebabkan oleh berbagai hal seperti tidak memakai alat pelindung diri, tidak mengikuti prosedur kerja, tidak mengikuti peraturan keselamatan kerja maupun bekerja tidak hati-hati. Dengan memahami manfaat dan dampak yang di timbulkan jika tidak menggunakan alat pelindung diri, maka akan mendorong responden untuk patuh dalam penggunaan APD.

\section{KESIMPULAN DAN SARAN}

\section{Kesimpulan}

Berdasarkan hasil penelitian tentang hubungan pengetahuan dengan kepatuhan perawat dalam penggunaan 
APD pada ruang Sindur dan Akasia RSUD Sultan Imanuddin Pangkalan Bun Kalimantan Tengah tahun 2021 dapat disimpulkan bahwa:

1) Pengetahuan responden tentang APD di ruang Sindur dan Akasia RSUD Sultan Imanuddin Pangkalan Bun, sebagian besar memiliki pengetahuan baik.

2) Kepatuhan responden terhadap penggunaan APD di ruang Sindur dan Akasia RSUD Sultan Imanuddin Pangkalan Bun sebagian besar patuh.

3) Ada hubungan yang signifikan antara pegetahuan dengan kepatuhan perawat dalam penggunaan APD di ruang Sindur dan Akasia RSUD Sultan Imanuddin Pangkalan Bun.

\section{Saran}

1) Bagi isntitusi pendidikan

Penelitian ini dapat menjadi informasi terkait dengan pendidikan di bidang kesehatan yang mengintensifkan kepada mahasiswa terkait dengan penggunaan APD khususnya pada penggunaan alas kaki khusus tentang manfaat dan dampak yang di timbulkan jika tidak memakainya.

2) Bagi Rumah Sakit

Pihak RSUD Sultan Imanuddin sebaiknya meningkatkan pengawasan kepada perawat dalam penggunaan APD khususnya pemakaian alas kaki khusus pada saat melakukan tindakan keperawatan.

3) Bagi Perawat Kepada pihak perawat sebaiknya saat melakukan tindakan keperawatan harus mengikuti prosedur penggunaan APD yang telah ditentukan dan lebih disiplin dalam penggunaan alas kaki khusus.

4) Bagi Peneliti Selanjutnya

Penelitian ini dapat memberikan masukan untuk meneliti lebih lanjut terkait perilaku perawat dalam penggunaan alas kaki khusus pada saat melakukan tindakan keperawatan.

\section{DAFTAR PUSTAKA}

Alimul H, Aziz. 2007. Metode Penelitian Keperawatan dan Teknik Analisis Data. Jakarta: Salemba Medika.

Anggreni, T. 2000. Universal Precaution Guadlines for Primary Health Care in Indonesia Initiative. Surabaya. Arikunto, S. 2002. ProsedurPenelitian, Suatu Pendekatan Praktek. Jakarta: PT. Rineka Cipta.

Arikunto, S. 2005. Manajemen Penelitian. Jakarta: PT. Rineka Cipta. Azwar. 2007. Sikap Manusia dan Pengukurannya. Jakarta: PT. Rineka Cipta.

Asri Raras M, Pratiwi Sri G. 2012. "Analisa Beban Kerja Untuk Menentukan Jumlah Optimal Karyawan Dan Pemetaan Kompetensi Karyawan Berdasarkan pada Job Descrition".

Darmadi. 2008. Infeksi Nosokomial: Problematika dan Pengendaliannya. Jakarta: Penerbit Salemba Medika.

Depkes RI. 2003. Pedoman Pencegahan dan Penanggulangan Infeksi Nosokomial di ICU. Jakarta. Habni, Yulia. 2009. Perilaku Perawat dalam Pencegahan Infeksi Nosokomial di Ruang Rindu A, Rindu B, ICU, IGD, Rawat jalan di RSUP H. Adam Malik Medan. 
Fudyartanta, 2012, Psikologi Kepribadian, Yogyakarta: Pustaka Pelajar

Kurnia P, Moch. Udin. 2012. Hubungan Tingkat Pengetahuan dan Sikap dengan Perilaku Penggunaan Alat Pelindung Diri pada Mahasiswa Profesi Fakultas Ilmu Keperawatan Universitas Indonesia.

Machfoedz, Ircham. 2008. Metodologi Penelitian Bidang Kesehatan, Keperawatan, Kebidanan, Kedokteran. Yogyakarta: Fitramaya.

Mubarak. 2011. Perilaku Kesehatan. Jakarta: Gramedia Pustaka Umum.

Notoatmojo, S. 2003. Pendidikan dan Perilaku Kesehatan. Jakarta: PT. Rineka Cipta.

Notoatmojo, S. 2010. Ilmu Perilaku Kesehatan. Jakarta: PT. Rineka Cipta.

Potter \& Perry. 2005. Buku Ajar Fundamental Keperawatan. Volume 1. Jakarta: EGC. Sugiyono. 2009.

Metode Penelitian Kuantitatif, Kualitatif, dan R \& D. Bandung: Alfabeta. Suma'mur. 2009. Higiene Perusahaan dan Kesehatan Kerja (HIPERKES). Jakarta: Sagung Seto.

Wawan, A. dan Dewi, M. 2010. Teori Pengukuran Pengetahuan, Sikap dan Perilaku Manusia. Yogyakarta: Nuha Medika. 